\title{
China's Maritime Ambiguity: A Neoclassical Realist Analysis and How it Shaped the Theatre of Conflict In the Disputed Seas
}

\author{
Heriawan* \\ International Relations Department \\ Universitas Indonesia \\ Depok, Indonesia \\ heriawanm@hotmail.com
}

\author{
Flory Abiwawanti \\ Independent Researcher \\ Jakarta, Indonesia \\ abiwantiflory@live.com
}

\begin{abstract}
China's assertiveness in the East and South China Sea (ESCS), complemented with paradoxical behavior on promoting international maritime cooperation, has left many to conclude that Beijing uses a dual strategy. To expand China's foreign policy's interpretation, we present an alternative approach with a neoclassical realist analytical framework to supplement the maritime security perspective. By accommodating domestic political changes, we explain the causal process that leads to China's maritime ambiguity and illustrates how it shaped the theater of conflict in ESCS. Understanding the disputes from the framework of unitlevel factors such as state-especially in China's local political dynamics - can bring a novel dimension to the discussion. We argue China's military reform to build a “true maritime power”（海洋强國）through the utilisation of the grey zone strategy via the China Coast Guard (CCG) plays a significant role in intervening against international politics' dynamic to deter the possibility of high-intensity conflict. Thus, the maritime security of rival country is more focused on how to deal with (1) non-traditional challenges in the sea such as piracy and (2) intergovernmental confidence building through the means of white hull diplomacy-while countering China's ambition on claiming the rights and interests in ESCS 'under the threshold of war.'
\end{abstract}

Keywords-China, East and South China Seas, Maritime Security, Neoclassical Realism, White Hull

\section{INTRODUCTION}

In March 2021, after the enactment of the new controversial coast guard law, 220 of Chinese boats occupied territorial waters in South China Seas near Whitsun Reef. The Philippines is concerned with the existent of the boats "due to the possible overfishing and destruction of the marine environment, as well as risks to safety of navigation'. [1]. An official from China says, "The Philippines shouldn't worry, they're just normal fishing boats, sheltering from storms." [2]. But the vessels are larger than normal fishing boats standard, and they never seem to catch any fish. The vessels are fast with top speed of around 18 to 22 knots, full-fledged weaponise with reinforced hulls, making them very dangerous at a close range. In short, they're not fishing boats, they're warships camouflaged as fishing boats as a part of China maritime militia.

This bizarre action can only be happening because of the new China's coast guard law. The law provides legal guarantees for effectively safeguarding national sovereignty, security, maritime rights and interest in the seas that China claims as its own. Furthermore, the law gives China Coast Guard (CCG), the rights to use weapons against foreign vessels that enter their territorial waters [3]. Considering there are numerous territorial disputes between China and its neighbors in the East and South China Seas (ESCS), this law is 'alarming' and an act of non-compliance to international law.

Under the Xi Jinping administration, China has been responsible for a good deal of assertive behaviour in the region. If we were looking back at Xi's epic vision for China in 2012, calling it "the great rejuvenation of the Chinese nation" or the pursuit of the “Chinese dream”（中 国夢 ） [4]. it emphasized China's ambition to become great power, combine it with $\mathrm{Xi}$ Jinping's view on "true maritime power"

(海洋强國), Xi wanted to recreate China’s traditional maritime order. This leads to numerous scholarly articles and books that argue China is developing into a more self-assured and aggressive posture in the region [5]-[9]. However, scholars often overlooked that China is also promoting international maritime cooperation. China becomes more open on its economic relations, and actively engaging with international community, region-wise. Some scholars propose a more compelling argument on this behaviour, calling it "dual strategy approach" [10] or "the Dao of foreign policy" [11]. 
China is exercising a considerable self-restraint in its diplomacy [12].

The dual strategy of coercion and inducement has been an effective way for China to interact with individual states in Asia - a combination of calibrated proportion of threat and inducement [10]. If we want to truly understand what it means for China to implement such an ambiguous foreign policy, we must explore several questions. How does China end up with this dual strategy approach, and how did ambiguous acts bring to realisation via the CCG? Can China maintain the conflict below the threshold of war by accommodating this strategy? To answer these questions, we utilised an extent revised model of neoclassical realist analytical theory that we developed, emphasising on one of the intervening variables: that is, the local dynamic politics of China-concerning the debates and views on Xi Jinping's CCG. In addition, CCG will be analysed under a maritime security perspective to give an accurate answer on how China expanded and utilised their Maritime Law Enforcement Agencies (MLEA) to control rights and interest in the contested seas.

This paper is structured as follows: the first section is a brief but critical introduction on the current development in the ESCS and review of the existing literatures on China's foreign and security ambiguity. The second section dedicated to give a thorough discussion on neoclassical realism as an analytical framework. It is worth to noted that neoclassical realism is not a sui generis theory, but an extension of realist traditions - both classical and structural realism. Next, still in the same section, we will make a hypothesis of China's conceptual perception on maritime security centred on China's navy-coastguard nexus. Due to the shortcoming of data collection, the third section, which is the results, will be bounded only to limited findings. Precisely, China's maritime security and the theatre of conflict in the ESCS from 2008 to the recent incident following the implementation of the new coast guard law-April 2021. We are well conscious of our limitation, therefore, at most, the discussion will be lacking. Finally, the paper concludes by summarising all the findings.

\section{NEOCLASSICAL REALISM AND CHINA'S MARITIME SECURITY ON THE EXPANDED NAVY-COAST GUARD ROLES}

\section{A. The Negligence of Realism on China's Foreign and Security Policy}

We begin this section by explaining the failure of realism to keep up with the development of China foreign and security policy in the ESCS disputes. The dominant realist analysis on China's behaviour in the region suffers from a narrow perspective of growing material power. Structural realist, either offensive or defensive realist, focus on the balance of power in the system. The core prediction of structural realist theory that the threatened states will balance against dangerous rising power by forming alliances or building arms or both has failed many times in the history. From the examination of Britain and France's behaviour in the 1930s to the Latin American War of the Triple Alliance from 1864-1870 [13]. There are two problems realist tends to overlook when discussing the contested waters. The first one is the misinterpretation of China's objectives in ESCS and the failure to recognise China's diplomatic approach in managing the disputes.

Realist believes growing power will lead to structural changes and rewrite the distribution of power capabilities among states [14], [15]. It is true that the rise of China's maritime military capabilities has changed the existing power structure. But, based on the rational expectation, in order to avoid the unbearable cost of war-since the power gap between ChinaUnited States (U.S.) is still huge-China will not challenge the existing hegemonic power. Logically, Xi Jinping's foreign and security policy should maintain self-restraint or peaceful rise, as Hu Jintao did. But the new coast guard law indicates a more aggressive approach. China behavioural changes is not only a result of growing relative power. It points out the fact that states behaviour are intervened by the other variables - domestically and internationally. Therefore, it is important to understand what is the role and core objectives of CCG. To what extent it is influenced by the external factors such as maritime security environment and other states responses to the CCG in the region.

Second, the paradoxical behaviour demonstrated by China signal ambiguous acts, a dual strategy of being aggressive as well as cooperative toward other claimant states ([10]-[12]). To have a better interpretation on the context and motives behind the ambiguous acts, we can look further at the local and political dynamics of China: that is, China's strategic maritime development. By doing so, this paper can improve the dominant realist analysis of China's rise, as well as validate the usefulness of neoclassical realism to analyse a defiant case in which classical and structural realism failed to explain.

\section{B. Neoclassical Realism Analytical Framework and the Local Political Dynamic of China}

Neoclassical realism accentuates the local political dynamics of a state more than other realist paradigms. Even though there is no particular neoclassical realism theory exist, it can be useful to construct an analytical framework for explaining the China ambiguity and CCG development. Neoclassical realism seeks to understand international politics by considering the nature of the international structure or system. Neoclassical realism postulate that: structural variables and cognitive variables can all explain the behaviour of a state. The core empirical prediction of neoclassical realism is that, over time, the relative amount of material power resources possessed by countries will shape the extent and ambition-or, as it were, the envelope - of their foreign policies [16]. States will search for more influence abroad as their power capabilities increases, and as it falls, states behaviour and goals are bound to scaled back accordingly. In sum, neoclassical realism argues that foreign policy as a 
dependent variable is affected by both independent and intervening variables. While, the independent variables are the systemic or structural nature of the international politics, provide an internally cohesive debates between scholars. The intervening variables on the other hand has inherent limitation, since it has utilised various domestic variables - ranging from political institutions, strategic culture, to leaders' perceptions [17, p. 84].

This problem is addressed under the two most notably neoclassical realist, Liu [18] and Ye [17]. Before them, there is Sørensen (2013) who wrote a fundamental argument on the independent variables in the case of China's rise. Sørensen argued that the rise of China is taking place in a unipolar system dominated by one superpower, the United States. In a unipolar system, where no serious challenger exists to the position of dominant power, the risk of misperception and conflict slims down, ensuring the stability of the international structure [19, p. 372]. But, Sørensen rhetorically explain China as powerless to control and appease radical and irrational nationalist sentiment that pressures Chinese government to take a more assertive stance. Providing an ambiguous China as an effect of domestic clashes on strategic orientation. Although Liu and Ye also recognised the pattern of Sørensen's argument on unipolar system. What interesting is Liu revised early neoclassical realist model by including dyadic-level in addition to systemic and domestic factors. Liu argued that systemic factors provide opportunities and challenges for the rising power and shape its realisation of strategic objectives. While, the domestic factors construct rising power preferences regarding the use of coercion to achieve its goals. At the same time, neighbouring countries' strategic responses become the other intervening variables to influence rising power's willingness to reassure them.

Thus, maintaining relations with great powers and neighbours simultaneously become equally important in China's foreign and security policy. Ye then implements this analysis further to mapped-out the transition that happening in China's national interest, issue a compelling argument on China interstate relations. Ye's findings concludes that China's foreign and security policy today-under the Xi Jinping's administration - has an adversary core interest. But it does not imply offensiveness or aggressiveness in foreign behaviour. Such an adversarial attitude can be interpreted as a passive reaction to U.S. containment [17, p. 102]. Implying a more self-restraint policy by China.

\section{The Absence of War}

The explanation and findings in the existing literatures lead us to the question on how such an ambiguous behaviour brought to realisation by CCG in the ESCS. To answer that, this paper analytical framework is based on the extent of neoclassical realism revision model, which has been introduced by Liu and then utilised by Ye to trace the transition in China's national interest. We analyse the utilisation of CCG to carry the ambiguous acts: coercive and cooperative action in the region regarding the disputed seas under the neoclassical realism paradigm and maritime security concept from the perspective of China. Nonetheless, the current theoretical model are not sufficient to answer our next question, can China maintain the conflict below the threshold of war by accommodating ambiguous strategy? With this in mind, the paper aims to improve the state-of-the-art of neoclassical realism on explaining modern conflict, where the concern of the possibilities of war is always on the air. Until now, neoclassical realism is bound to explain foreign policy, differ from one of its original root-structural realism - to explain the international politics. Limiting itself to the possibility of explaining of the most interesting developments in $21 \mathrm{st}$ international politics, that is, the absence of war.

Specific to our study case, the prolonged disputes in the ESCS, we argue that China ambiguity has shaped the theatre of conflict in the ESCS. The interplay between each variable, independent and intervening variables can be expressed using this equation: distribution of power + China strategic orientation + other claimant states' response = China foreign and security policy $=$ the theatre of conflict in the ESCS. China taking advantage of the U.S. unipolarity. Next to Xi Jinping's dedication on striving for "true maritime power", result in a modernised coast guard and MLEA transition to be a single agency. While, competing claims have put China at odds with Japan and other Southeast Asian countries, pushing regional alliances to at least soft balancing China. Even though, at some extent, it is true that some countries are opposing China's maritime actions-developing their naval capabilities and strengthening ties. China's white hull diplomacy and economy means play a big role in this situation. From this, we formulate China's ambiguity as a means to avoid or restrict rivals' responses, resulting in a theatre of conflict where war or high-intensity conflict is forbidden.

Although it may be true that China coercion could indicate their preparedness for war [20]. In the meantime, it is more suitable to categorized China's MLEA as a grey zone strategy. Indeed, the force is intended to stay below the threshold of war. They strategically planned and justified to avoid the cost of war. As a result, China's ambiguity created a maritime security environment where grey zone or low-intensity operation is mandatory in the disputed seas. To further elaborate this point, we begin the next sub-section to discuss the conceptual debate on maritime security to giving a comprehensive understanding on China's expanded navy-coastguard role in the ESCS.

\section{Maritime Security and The China Coast Guard Roles}

Maritime security as a concept does not have a clear definition on what kind of action or actors are considered as a threat. It is one of the latest buzzwords on international relations [21]. There is still no international consensus over the definition. For that reason, the effort that states will take to ensure their maritime security is widely different from one to another. Sam Bateman [22] said, "countries with small 
maritime domain tend to limit their interpretation of maritime security only to traditional issues such as military threats and the protection of national interests and sovereignty at sea". Countries with a relatively small maritime zone and distant from the water, such as Thailand and South Korea, are uncomfortable to include Illegal, Unreported or Unregulated (IUU) fishing within their scope of maritime security [22, pp. 3-4].

Meanwhile, a country with larger maritime domain will expand the definition to include everything from traditional security issues to environmental threats and illegal fishing. China, of course, is more inline with the expanded definition with their concept of harmonious ocean. China's harmonious ocean reflects the inward objectives of China's naval development over the past 60 years. Quoted from 14th Five-year Plans (FYP) of China: "Harmony between humanity and the ocean, win-win cooperation, and pushing forward with conservation of ocean ecologies," were mentioned in the chapter introduction [23]. It means all the countries in the world should presently protect their ocean against damage from international conflicts and crises. Including prevention of outside aggression, defense of the national territory, safeguarding a secure environment for national economic development, and political and social stability.

Country perception on realpolitik vs rules-based will also influence how they perceived maritime security. In the sea, United Nations Convention on the Law of the Sea 1982 (UNCLOS) is the norm to refer when it comes to rights and responsibility to safeguard the water. Rights for freedom of navigation, rights, and sovereignty for natural resources, and the responsibility to protect the sea from threats. To maintain stability and harmony are the core principle for a country with rulesbased view. In this environment, Code of Conduct $(\mathrm{CoC})$ will be the dominant priority to solve disputes. As illustrated in the case of China's claim on Scarborough Shoal in South China Sea (SCS) where the permanent Court of Arbitration is favoring the Philippines claim. Even so, it does not mean China will take it for granted. Realpolitik is undoubtedly characterised in China's view-whereas the distribution of power and the intensity of conflict is a far more important factors.

Last but not least, countries' navy coast-guard nexus can also influence maritime security perception. State which differentiates their navy (military/defense) and coast guard (law enforcement) roles is more likely to have expanded definition on maritime security. Despite that, countries which blurred the distinction between each institution does not always translate a limited perception on maritime security. In 2013, China relied on at least five major maritime administrative agencies. They were the 'Five Dragons': AntiSmuggling Bureau (ASB), the China Maritime Police Bureau also known as the China Coast Guard (CCG), China Maritime Surveillance (CMS), the Fisheries Law Enforcement Command (FLEC), and the Maritime Safety Administration (ASB). Prior to CCG, Since the reorganization under the centralized command of the
Chinese Communist Party Central Committee and the Central Military Commission (中央军事委员会) in 2016, CCG have become more military related.

Arguably, CCG may have similar destructive and offensive capabilities with the People's Liberation Army (PLA) Navy. Making them one of the most dangerous ships in the seas. Within the new coast guard law, CCG will have more flexibility on controlling the seas, more freedom of action, and more reason to deny other claimant' states claim for China's own purposes. From this, we believe-based on all the factors that affect China's maritime security perception-China's "true maritime power" is a manifestation of their responses to the challenges and threats in their maritime environment. Thus, powerful maritime order is a must for China in the region. This created a maritime security environment where grey zone or low-intensity operation is mandatory in the disputed seas.

\section{THE THEATRE OF CONFLICT IN THE EAST AND SOUTH CHINA SEAS}

\section{A. Theatre of Conflict in the Southern Part of Contested Sea}

In SCS disputes, China has put on quite a show over the years. The tension is consistently growing and taking up global concerns. Beijing has been more engaged in the region, establishing a government body in the Paracel Islands, a prefecture-level city named Sansha city on Yongxing Island - one of the SCS's numerous contested territories. More to the south, China's reclaimed Spratly Islands and built airstrips on three of the islands it controls: the Fiery Cross Reef, Subi Reef, and the Mischief Reef zones surrounding the Senkaku Islands [24]. To bolster its territorial claims, China has imposed unilateral fishing bans and established Xisha and Nansha district, two new areas in the SCS for the disputed Paracel and Spratly Islands. The two cities were situated under the administrative region of Sansha City. CCG vessels are very active in the location, it harassed other claimants' marine research ships and fishing boats regularly. From 2010 until 2016, there were 45 cases reported in the SCS involving clashes and standoffs. Unsurprisingly, from those 45 cases, 30 of them are involving China's coast guard [25]. CCG was assertively protecting China's interest to the point that they were involved in clashes in SCS. These actions have harmed the interest of regional claimants for the past decade.

China practices sometimes appear to be problematic, it is not hesitant for a clash with fishing boats and other vessels coming from other claimant state. In April 2020, a CCG ship sank a Vietnamese fishing boat, an action that led the region to a swirl of diplomatic protests from around the region [26]. As recent as April 2020, Haiyang Dizhi (Chinese Survey Ship) attacked Petronas' (Malaysia) West Capella oil and gas exploration in the SCS territory closer to the shore [27]. Before that, in December 6-9, two CCG vessels (the Haijing $5202 \& 5403$ ) watched over the area of the West Capella. Later on, this activity would 
eventually result in a highly public standoff with Indonesia [28]. Tension in the SCS is rising as a result of quick and enormous land reclamation as well as increasingly regular CCG and submarine activities. In addition to those factors, the U.S.' freedom of navigation missions within the Chinese artificial islands is also enthralling.

Chinese military advancements and 'bullying enforcement' in Southern sea have risen the tension over the region. However, while at some extent, it is true that ASEAN countries are opposing China's maritime actions. There is no apparent alliances dedicated to balance China. Instead of balancing, most countries are also self-restraint. China plays a big role in the other claimant states' economy. Take for example the Philippines who is benefited from its relation with China in the mids of COVID-19 Pandemic. Because of that, "The President Duterte said 'nothing will happen' if the nation sends its ships "because we are not in the possession of the sea." [2] when questioned about China's white hulls in Whitsun reef. Granted, other claimant states' response is conceptually accurate to be described as hedging. This recent trend has been used more to show China's soft power play throughout the other claimant states'. Earlier that year, China sent more its coast guard ship to the Philippines as a part of new diplomacy yet also seen as a friendly persuasion to soften what have been understood by confrontation before. Vessel 5204 visited Manila South Harbour in January 2020 to help bring aid for the displaced persons affected by volcano eruption [29]. China and Philippine have also been known to perform joint military drill on the claimed waters. This development has shown China's effort to stand on grey zone, avoiding escalation of its assertive efforts in Southern seas.

\section{B. Theatre of Conflict in the Eastern Part of Contested Sea}

East China Sea (ECS) is pretty self-explanatory: it is located eastern to the China and sharing a common border with three major East Asian countries: China, Japan, and South Korea. Although the three countries have major diplomatic and economic interactions, the disputes didn't stop China from projecting its claim. One of the five islands in the chain is Senkaku/Diaoyu island. Regarding the existing state of affairs, China and Japan have signed a fisheries' agreement in 2000 to cooperatively develop fisheries resources in the ECS. Nevertheless, the pact did not include Senkaku/Diaoyu island. Many efforts have established to reduce the growing risk of maritime confrontation, as well as crisis management systems. Unfortunately, China's is not a dutiful one. The government started to infringe the Japanese territorial waters with lots of white hull ships since December 2008. Move forward to 2012, the infringement increased drastically, the only period where the white hull vessels are slowing down happened at the end of 2013. Yet, since then, China's white hull vessels continue to patrolling the zone on a regular basis. Perhaps one of the most controversial acts happened in December 2015, when China send fully weaponised coast guard vessels to challenge Japanese territory around the ECS [24].
Unlike the Southern sea, the theater of conflict in the Eastern sea include air shows. The amount of China's naval aviation air force aircraft flying at the Japanese airspace is alarming. The international world has been disturbed by the establishment of China's East China Sea Air Defense Identification Zone (ADIZ) above the territory. The zone allowed a coastal state (China) to "identify, monitor, control, and react to aircraft that cross the zone with potential air threats". The number of Chinese official vessels are increased drastically in 2019. Early in the next year, China heightened tensions by expanding the presence of CCG vessels in the contiguous zone [30]. On a period of August 2019 to August 2020, these vessels were inside the contiguous zone for 456 days out of 519. Even though this presence is frightening to Japan, so far, China breaks no agreement on this action according to Article 33 of the UNCLOS: that is, foreign vessels enjoys high sea freedom in the contiguous zone as long as they do not retaliate coastal state rights concerning the EEZ. There were also numerous Chinese fishing boats roam throughout the waters of Senkaku/Diaoyu Island. The Number spiked around 300 Chinese fishing trawlers with CCG maneuvered in and out around them. This action is a strategy to undermine Japan's sovereignty and administrative control.

\section{In a Broader Context}

Each of the disputes offers a different setting on how China presented its course of action. In southern sea, China is more assertive - arguably aggressive - as it prefers to do outright action towards its contender. Whereas, in the eastern sea, China is seen to dispose its step on a low profile. This bewildering behaviour is a result of China's naval development and the capability of naval assets to conduct operations below the level of open war. With the multi-mission in mind, the PLA Navy and CCG can also focus on noncombat activities, such as search and rescue exercises (SAREX). For example, a Chinese frigate coordinated with naval ships from Bangladesh, Iran, and India to practice searching for missing boats in November 2017 as part of the Indian Ocean Naval Symposium. While not technically an exercise, the PLA Navy "maritime parade" in April 2019 featured coordinated maneuver between ships from 13 countries and thus shared some features common to multilateral exercises [31].

The CCG, through the new law, is projected to be a safer menace to show China's claim but also to be a guardian for its counterpart countries in the Southeast and Greater Asia. Back in August 2011, Vietnam and China initiated strategic dialogue at the deputy ministerial level. In their second strategic dialogue, both countries agreed that military exchanges would be increased, and a hot line between the two defense ministries is established. Later on, at their sixth security dialogue in September 2012, the two countries agreed to "continue high-level visits, strengthen dialogue and consultation, promote cooperation in the fields of personnel training, border exchange, naval and multilateral security issues" [32]. Initially, China and Vietnam joint patrol comprised day and sight 
signaling drills as well as an anti-piracy training. By the first half of 2014, there had been a total of 16 joint patrols. Despite the lingering differences between China and Vietnam, they widen their scope of joints patrol at the Tonkin Gulf in April 2016.

China maritime diplomatic effort is not limited to the ESCS. For example, regarding the Indian Ocean, the diplomacy represented by building ports. China built a deep-water port at Kyauk $\mathrm{Pu}$, Myanmar as well as one in Hambantota, Sri Lanka. China also established its first overseas military base-Doraleh Multipurpose Port-in on Africa's east coast, Djibouti. The location is crucial for China to project its power across African and Asia. However, Gwadar Port in Pakistan - a part of China-Pakistan Economic Corridor (CPEC) - still a major entry point for China. This port has served as the PLA Navy Naval Base since 2017 and for the next 40 years. The ports and military installation would strengthen the PLA Navy's position in the Indian Ocean [33]. The PLA Navy sent a hospital ship Peace Ark to St. George, the capital of Grenada, in 2018. The Chinese crew carried out medical examinations and treatment for thousands of residents for a long eight days. The Peace Ark's port call tried to reflect a modernizing navy's pride in its ability to showcase its sleek, sturdy ships and build international good will [31].

\section{CONCLUSION}

China's ambition to fulfil its "true maritime power" via coercion and cooperative means is a natural and logical decision to make. Therefore, with this paper, we explore and extend the possibility of neoclassical realism to explain — or may predict - the international politics. Especially within the unique landscape of Asia's regional maritime security and disputes in it. Xi's strong desire to strive for "true maritime power" has sparked tension with other claimant states', causing them to have doubts on China's willingness to utilise its power responsibly as a stakeholder. But the interdependence of marine and economic cooperation trumps the uncertainty.

The theatre of conflict in ESCS is not always rigid - most of the time, it is vague and ambiguous. The local political dynamic of China; represented by the expansion of its naval and MLEA capabilities - not restricted only to military power. The PLA Navy and CCG have all carried out both bilateral and multilateral exercises. The newest law on coast guard earlier this year will amplify China's maritime coercion to a degree where war is not an option for every party involved. Combine it with the Chinese maritime diplomacy or white hull diplomacy, it is hard to consider China as a full threat from the perspective of countries that benefitted from it. China's lukewarm assertiveness is a tactic to manage the tension in the region. By design, the conflict was strategically planned to be below the threshold of war. An act of military can be seen as provocative and contradictory.

\section{ACKNOWLEDGMENT}

The co-author would like to express his very great appreciation to the main supervisor of this research, Mr. Ali Abdullah Wibisono. He is particularly grateful for the assistance given by Kirana Virajati. He Would also like to thank Fathurrahman and Muhammad Maulana Iberahim for proofreading the article.

\section{REFERENCES}

[1] 'Wary Philippines says 200 Chinese vessels at disputed reef', CNBC, Mar. 21, 2021 https://www.cnbc.com/2021/03/21/whitsun-reef-philippinessays-200-chinese-vessels-in-filipino-eez.html (accessed May 30, 2021).

[2] China Uncensored, "It Will Be Bloody"-Philippines' South China Sea Warning, (Apr. 24, 2021). Accessed: May 30, 2021. [Online Video]. Available: https://www.youtube.com/watch?v=-zEjo4ALbds

[3] Z. Haver, 'China Passes Law Allowing Coastguard to Use Force Against Foreign Vessels', Radio Free Asia. https://www.rfa.org/english/news/china/coastguard-law01222021190658.html (accessed May 29, 2021).

[4] G. Allison, 'What Xi Jinping Wants', The Atlantic, May 31, 2017.

https://www.theatlantic.com/international/archive/2017/05/w hat-china-wants/528561/ (accessed May 29, 2021).

[5] K. Morton, 'China's ambition in the South China Sea: is a legitimate maritime order possible?', International Affairs, vol. 92, no. 4, pp. 909-940, Jul. 2016, doi: 10.1111/14682346.12658 .

[6] C. Rahman and M. Tsamenyi, 'A Strategic Perspective on Security and Naval Issues in the South China Sea', Ocean Development \& International Law, vol. 41, no. 4, pp. 315333, Nov. 2010, doi: 10.1080/00908320.2010.499277.

[7] D. P. Shah, 'China's Maritime Security Strategy: An Assessment of The White Paper nn Asia-Pacific Security Cooperation', Maritime Affairs: Journal of the National Maritime Foundation of India, vol. 13, no. 1, pp. 1-13, Jan. 2017, doi: 10.1080/09733159.2017.1317122.

[8] G. de Jonquières, 'de Jonquieres, Guy. 2014.pdf', International Journal of China Studies, vol. 5, no. 2, pp. 399412, 2014

[9] Y.-H. Lim, China's naval power: an offensive realist approach? London: Routledge, 2014.

[10] H. Le Thu, 'China's dual strategy of coercion and inducement towards ASEAN', The Pacific Review, vol. 32, no. 1, pp. 2036, Jan. 2019, doi: 10.1080/09512748.2017.1417325.

[11] M. Rosyidin, 'The Dao off foreign policy: Understanding China's dual strategy in the South China Sea', Contemporary Security Policy, vol. 40, no. 2, pp. 214-238, Apr. 2019, doi: 10.1080/13523260.2019.1565374.

[12] Z. Fangyin, 'Between assertiveness and self-restraint: understanding China's South China Sea policy', International Affairs, vol. 92, no. 4, pp. 869-890, Jul. 2016, doi: $10.1111 / 1468-2346.12657$.

[13] R. L. Schweller, 'Unanswered Threats: A Neoclassical Realist Theory of Underbalancing', International Security, vol. 29, no. 2, pp. 159-201, Oct. 2004, doi: $10.1162 / 0162288042879913$.

[14] K. N. Waltz, Theory of international politics, 1st ed. Boston, Mass: McGraw-Hill, 1979.

[15] J. J. Mearsheimer, The tragedy of Great Power politics. New York: Norton, 2001.

[16] G. Rose, 'Neoclassical Realism and Theories of Foreign Policy', World Pol., vol. 51, no. 1, pp. 144-172, Oct. 1998, doi: $10.1017 / \mathrm{S} 0043887100007814$.

[17] X. Ye, 'Rediscovering the Transition in China's National Interest: A Neoclassical Realist Approach', Journal of Current Chinese Affairs, vol. 48, no. 1, pp. 76-105, Apr. 2019, doi: 10.1177/1868102619876830. 
[18] F. Liu, 'China's Security Strategy towards East Asia', Chinese Journal of International Politics, vol. 9, no. 2, pp. 151-179, Jun. 2016, doi: 10.1093/cjip/pow003.

[19] C. T. N. Sørensen, 'Is China Becoming More Aggressive? A Neoclassical Realist Analysis', Asian Perspective, vol. 37, no. 3, pp. 363-385, 2013, doi: 10.1353/apr.2013.0014.

[20] A. Patalano, "When strategy is "hybrid" and not "grey": reviewing Chinese military and constabulary coercion at sea', The Pacific Review, vol. 31, no. 6, pp. 811-839, Nov. 2018, doi: 10.1080/09512748.2018.1513546.

[21] C. Bueger, 'What is maritime security?', Marine Policy, vol. 53, pp. 159-164, Mar. 2015, doi: 10.1016/j.marpol.2014.12.005.

[22] S. Bateman, "Solving the "Wicked Problems" of Maritime Security: Are Regional Forums up to the Task?', CS, vol. 33, no. 1, p. 1, 2011, doi: 10.1355/cs34-1a.

[23] J. Yifan and S. Yi, 'The ocean in China's 14th Five Year Plan | China Dialogue Ocean', chinadialogue ocean, Apr. 08, 2021. https://chinadialogueocean.net/16944-ocean-china-14th-fiveyear-plan/ (accessed Jul. 04, 2021).

[24] R. Dossani and S. W. Harold, 'Maritime Issues in the East and South China Seas: Summary of a Conference Held January 12-13, 2016', p. 141.

[25] G. Torode, 'Chinese coast guard involved in most South China Sea clashes: research', Reuters, Sep. 07, 2016. Accessed: Jul. 05, 2021. [Online]. Available: https://www.reuters.com/article/us-southchinasea-chinacoastguard-idUSKCN11C2LA

[26] S. A. Thornton, 'Averting conflict in the South China Sea: Steps to restore rules and restraint', 2020.
[27] S. V. Muhammad, 'Escalation of tension in South China Sea and ASEAN Stance', Info Singkat, vol. 12, no. 10, pp. 7-12, May 2020.

[28] 'Malaysia Picks a Three-Way Fight in the South China Sea', Asia Maritime Transparency Initiative. https://amti.csis.org/malaysia-picks-a-three-way-fight-in-thesouth-china-sea/ (accessed Jul. 06, 2021).

[29] K. Huang, 'China likely to step up South China Sea soft power play', South China Morning Post, Jan. 19, 2020. https://www.scmp.com/news/china/military/article/3046500/ china-likely-step-coastguard-port-calls-part-south-china-sea (accessed Jul. 07, 2021).

[30] M. Mochizuki and J. Han, 'Is China Escalating Tensions with Japan in the East China Sea?' https://thediplomat.com/2020/09/is-china-escalatingtensions-with-japan-in-the-east-china-sea/ (accessed Jul. 05, 2021).

[31] T. R. Heath, 'China Maritime Report No. 8: Winning Friends and Influencing People: Naval Diplomacy with Chinese Characteristics', 8, 2020.

[32] C. A. Thayer, 'Vietnam's Strategy of "Cooperating and Struggling" with China over Maritime Disputes in the South China Sea', Journal of Asian Security and International Affairs, vol. 3, no. 2, pp. 200-220, Aug. 2016, doi: $10.1177 / 2347797016645453$

[33] J. Tertia and A. A. B. Perwita, 'Maritime Security in IndoPacific: Issues, Challenges, and Prospects', JIHI, vol. 14, no. 1, p. 77, May 2018, doi: 10.26593/jihi.v14i1.2795.77-95. 